\title{
MODUL PEMBELAJARAN IPA TERPADU PADA MATERI TANAH DAN KEBERLANGSUNGAN KEHIDUPAN
}

\author{
Elvi Rapilus ${ }^{1)}$; Basa T Rumahorbo ${ }^{2)}$; Virman ${ }^{3)}$ \\ ${ }^{1}$ SMP Negeri 2 Manokwari ; elvi.rapilus67@gmail.com \\ ${ }^{2}$ Program Studi Magister Pendidikan IPA UNCEN ; basarumahorbo3454@gmail.com \\ ${ }^{3}$ Program Studi Magister Pendidikan IPA UNCEN ; virman_uncen@yahoo.com
}

\begin{abstract}
Science learning modules on soil material and life sustainability have never been made especially in SMP Negeri 2 Manokwari. This research is a research and development (Research \& Development) that aims to find out how to make integrated science modules, the feasibility of integrated science modules, and increase learning outcomes in soil material and the sustainability of life. The research sample was carried out in class IX E SMP Negeri 2 Manokwari with a total of 38 students. The results of the study show that: 1) The method of developing an integrated science module based on guided inquiry on soil material and life sustainability starts with the stages of definition, module planning, module draft design, and development. from the validator of $88 \%$ in the very feasible category, science teachers by $90 \%$ in the very feasible category, and the results of small-scale trials by $89 \%$. 3) Increasing student learning outcomes with an average pretest score of 35.72 to 71.11 in the posttest and $n$-gain tests an average of 0.55 in the medium category.
\end{abstract}

Keywords: Integrated Science Module; Land and survival.

\begin{abstract}
ABSTRAK
Modul pembelajaran IPA pada materi tanah dan keberlangsungan kehidupan belum pernah dibuat khususnya di SMP negeri 2 Manokwari. Penelitian ini merupakan penelitian dan pengembangan (Research \& Development) yang bertujuan untuk mengetahui cara membuat modul IPA terpadu, kelayakan modul IPA terpadu, dan peningkatan hasil belajar pada materi tanah dan keberlangsungan kehidupan. Sampel penelitian dilaksanakan di kelas IX E SMP Negeri 2 Manokwari dengan jumlah 38 peserta didik. Hasil penelitian menunjukkan bahwa: 1) Metode pengembangan modul IPA terpadu berbasis inkuiri terbimbing pada materi tanah dan keberlangsungan kehidupan dimulai dengan tahap pendefinisian, perencanaan modul, perancangan draf modul, dan pengembangan 2) Kelayakan modul IPA terpadu berbasis inkuiri terbimbing pada materi tanah dan keberlangsungan kehidupan dari validator sebesar $88 \%$ dengan kategori sangat layak, guru IPA sebesar 90\% dengan kategori sangat layak, dan hasil ujicoba skala kecil sebesar 89\%.. 3) Peningkatan hasil belajar peserta didik dengan rata-rata nilai pretest 35,72 menjadi 71,11 pada posttest dan uji $n$-Gain rata-rata 0,55 dengan kategori sedang.
\end{abstract}

Kata Kunci: Modul IPA Terpadu; Tanah dan keberlangsungan hidup.

\section{PENDAHULUAN}

Pendidikan merupakan salah satu sarana untuk mengembangkan dan meningkatkan sumber daya manusia yang berkualitas. Pengembangan potensi peserta didik merupakan salah satu tujuan dari pendidikan nasional. Keberhasilan peserta didik dapat dilihat dari peserta didik yang berkualitas, bermoral, dan berilmu yang dilakukan melalui proses pembelajaran. Ilmu yang diperoleh peserta didik dapat digunakan untuk mempelajari kehidupan dan proses kehidupan. Salah satunya adalah melalui pembelajaran IPA terpadu. 
Pembelajaran IPA terpadu adalah pembelajaran IPA yang mencoba memadukan beberapa pokok bahasan dari berbagai kajian (fisika,kimia, biologi) pada mata pelajaran IPA dalam satu bahasan (Depdiknas, 2006).Melalui pembelajaran IPA terpadu peserta didik dapat memperoleh pengalaman langsung dan menerapkan konsep yang dipelajarinya (Trianto, 2012). Pada umumnya pebelajaran IPA di SMP belum sepenuhnya dilaksanakan secara terpadu, dikarenakan beberapa faktor, antara lain: 1) belum ada guru yang memiliki latar belakang pendidikan IPA terpadu, 2) Bahan ajar IPA terpadu masih kurang memadai, 3) guru merasa nyaman dengan kebiasaan mengajarnya dan enggan untuk mencoba sesuatu yang berbeda.

Berdasarkan pengalaman peneliti dan guru yang mengajar mata pelajaran IPA terpadu di SMP Negeri 2 Manokwari, pembelajaran IPA masih cenderung dilakukan secara terpisah antara fisika, kimia, biologi karena guru masih kesulitan menyusun bahan ajar IPA terpadurapa fakta terkait proses pembelajaran IPA di SMP Negeri 2 Manokwari: 1) kemampuan akademik peserta didik bervariasi, 2) guru mengajar lebih sering menggunakan metode ceramah dan tanya jawab, 3) sumber belajar terbatas, 4) perserta didik cenderung pasif. Hasil belajar IPA terpadu kelas IX pada tahun lalu rata-rata belum mencapai KKM yaitu 70. Untuk mengatasi masalah tersebut salah satu solusinya adalah membuat perangkat pembelajaran berupa modul. Modul adalah sebuah media pembelajaran dalam bentuk buku yang ditulis dengan tujuan peserta didik dapat belajar mandiri tanpa atau dengan bantuan guru, yang disusun sistematis dengan bahasa yang mudah dipahami oleh peserta didik sesuai dengan tingkat usia dan pengetahuan mereka (Prastowo,2012). Modul IPA terpadu disusun dengan memuat informasi tentang materi, kegiatan praktikum, soal-soal dan juga disertai dengan gambar-gambar yang menarik sehingga dapat memotivasi dan meningkatkan minat belajar peserta didik memperoleh pemahaman serta dapat memecahkan suatu permasalahan.. Salah satu pendekatan yang dapat membantu peserta didik memecahkan suatu masalah adalah pendekatan inkuiri terbimbing.

Pendekatan berbasis inkuiri adalah suatu pendekatan yang digunakan dan mengacu pada suatu cara untuk mempertanyakan, mencari pengetahuan (informasi), atau mempelajari suatu gejala (Siregar Tiurlina, 2011). Pertanyaan merupakan inti dari pembelajaran berbasis inkuiri.Pertanyaan dapat menuntun untuk melakukan penyelidikan sebagai usaha peserta didik dalam memahami pelajaran (Nuh, 2009).Pembelajaran berbasis inkuiri merupakan kegiatan yang melibatkan secara maksimal seluruh kemampuan peserta didik untun mencari dan menyelidiki sesuatu secara sistematis, kritis, logis, dan analitis sehingga peserta didik mampu merumuskan penemuannya dengan penuh percaya diri (Putra, 2012). Materi tanah dan keberlangsungan kehidupan merupakan materi baru yang diajarkan di kelas IX yang bahan ajarnya masih terbatas dan sangat sesuai diajarkan dengan pendekatan inkuiri terbimbing.

Berdasarkan uraian di atas, maka peneliti melakukan penelitian tentang“ Modul 
IPA Berbasis Inkuiri Terbimbing Untuk Meningkatkan Hasil Belajar Peserta Didik Pada Materi Tanah dan Keberlangsungan Kehidupan di Kelas IX SMP Negeri 2 Manokwari.

\section{METODE PENELITIAN}

Metode dalam penelitian ini adalah penelitian dan pengembangan yang bertujuan membuat suatu produk yaitu modul IPA terpadu materi tanah dan keberlangsungan kehidupan kelas pendekatanpengembangan menggunakan kelas ujicoba skala kecil (terbatas) dan kelas ujicoba skala luas. Desain eksperimen yang digunakan adalah One Group Pretest- Posttest Design, yang terdiri dari satu kelompok eksperimen tanpa ada kontrol (Sugiyono, 2015) ditunjukkan pada Tabel 1 sebagai berikut :

Tabel 1

Model penelitian danPengembangan

\begin{tabular}{|c|c|c|c|}
\hline Group & $\begin{array}{c}\text { Perla } \\
\text { kuan }\end{array}$ & $\begin{array}{c}\text { Pre } \\
\text { test }\end{array}$ & $\begin{array}{c}\text { Post } \\
\text { test }\end{array}$ \\
\hline $\begin{array}{c}\text { Kelas Luas } \\
\text { (KL) }\end{array}$ & $\mathrm{X}$ & $\mathrm{O}$ & $\mathrm{O}_{1}$ \\
\hline $\begin{array}{c}\text { Kelas } \\
\text { Terbatas (KT) }\end{array}$ & $\mathrm{X}$ & - & - \\
\hline
\end{tabular}

Keterangan:

$\mathrm{X}$ menyatakan Pembelajaran menggunakan modul IPA terpadu berbasis inkuiri terbimbing, O menyatakan Pretest pada kelas luas dan $\mathrm{O}_{1}$ menyatakan Posttest pada kelas luas.

Populasi dalam penelitian ini adalah peserta didik kelas IX SMP Negeri 2 Manokwari Tahun ajaran 2018/2019. Sampel dalam penelitian ini adalah kelas IX E yang berjumlah 38 peserta didik.

Teknik pengumpulan data yang dilakukan dalam penelitian ini antara lain:
1) Penilaian kelayakan modul menggunakan lembar angket validasi ahli materi, angket respon guru dan angket peserta didik.

2) Lembar Obsevasi Keaktifan belajar peserta didik

3) Penilaian Hasil belajar menggunakan soal pretest dan posttest untuk mengukur hasil belajar sebelum dan sesudah penerapan produk (Riduwan, 2012)

\section{HASIL DAN PEMBAHASAN}

\section{Pengembangan modul pembelajaran} IPA terpadu berbasis inkuiri terbimbing pada materi tanah dan keberlangsungan

\section{kehidupan}

Pengembangan modul IPA terpadu berbasis inkuiri terbimbing materi tanah dan keberlangsungan kehidupan dilakukan dengan tahapan sebagai berikut: 1) analisis potensi dan masalah, 2) pengumpulan data, 3) desain produk, 4) validasi desain, 5) revisi desain, 6) ujicoba produk, dan 7) evaluasi. Tahapan ini sesuai dengan penelitian Simon K (2018).

\section{Kelayakan Modul IPA terpadu berbasis} inkuiri terbimbing pada materi tanah

\section{dan keberlangsungan kehidupan}

Kelayakan modul pembelajaran dapat dilihat validasi validator ahli materi.

Validasi ahli materi ditunjukkan pada gambar berikut:

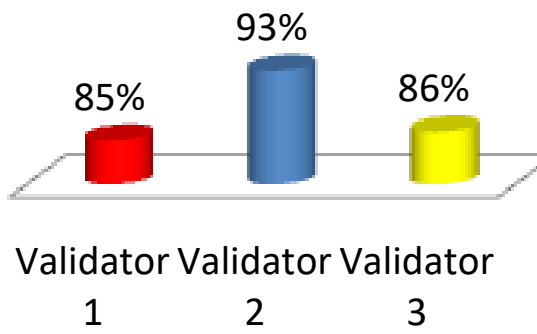

Gambar 1. Kelayakan modul oleh validator

Penilaian kelayakan materi meliputi komponen kelayakan isi, komponen kelayakan 
kebahasaan, dan komponen kelayakan penyajian modul. Berdasarkan gambar 1 hasil validasi dari validator materi diperoleh penilaian dari validator 1 sebesar $85 \%$, validator 2 sebesar $93 \%$ dan validator 3 sebesar $86 \%$. Rata -rata hasil penilaian dari ketiga validator adalah sebesar $88 \%$ dengan kategori sangat layak. Hasil penelitian ini didukung penelitian terdahulu Esti Rosalina dan Virman (2018) bahwa modul harus divalidasi oleh validator dan guru senior yang sesuai bidang atau serumpun.

\section{Hasi Uji Coba Modul}

a. Hasil Tanggapan guru ditunjukkan pada gambar berikut :

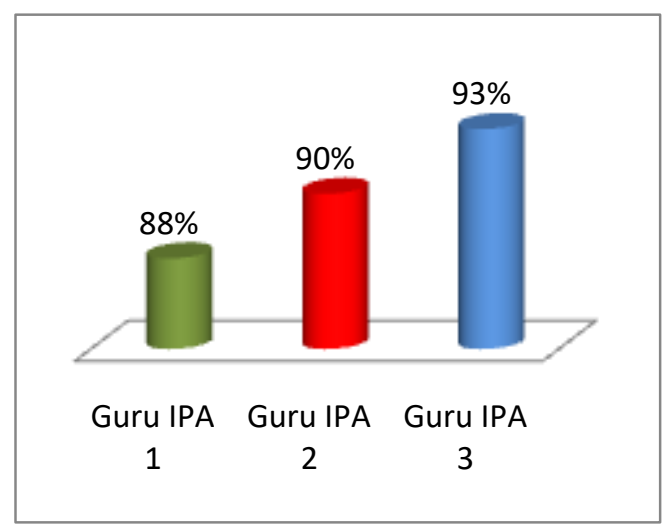

Gambar 2. Kelayakan modul oleh guru

Berdasarkan gambar 2 hasil tanggapan atau respon guru memperoleh persentase dari guru IPA 1 sebesar 88\%, guru IPA 2 sebesar 90\% dan guru IPA 3sebesar 93\%. Rata - rata persentase yang dipeoleh dari tanggapan atau respon guru adalah sebesar 90\% dengan kategori sangat layak.

b. Respon peserta didik pada uji skala kecil ditunjukkan pada gambar berikut :

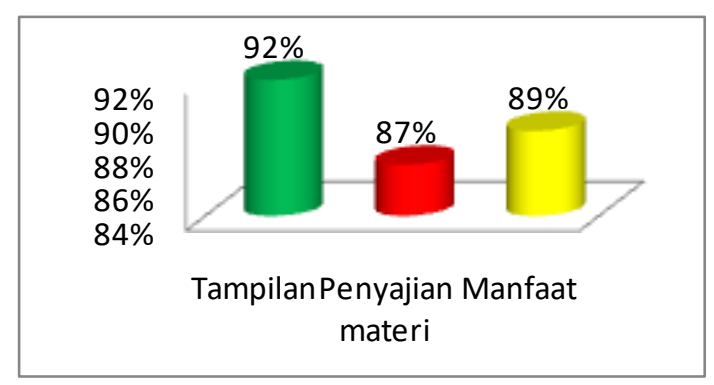

Gambar 3. Kelayakan modul oleh peserta didik

Hasil respon peserta didik pada skala kecil terhadap kualitas modul IPA terpadu: aspek tampilan, sebesar $92 \%$, aspek penyajian sebesar $87 \%$, aspek manfaat sebesar $89 \%$. Rata - rata respon dari peserta didik adalah sebesar $89 \%$ dengan kategori sangat layak.

\section{3) Hasil belajar peserta didik}

Peningkatan hasil belajar peserta didik terhadap materi tanah dan keberlangsungan kehidupan menggunakan nilai pretest dan posttest yang dianalisis menggunakan uji $n$ Gain.

Peningkatan hasil belajar berdasarkan hasil pretest dan posttestpada RPP-1,RPP-2, RPP-3 dan RPP-4dan hasil uji $n$-Gainditunjukkan pada gambar berikut :

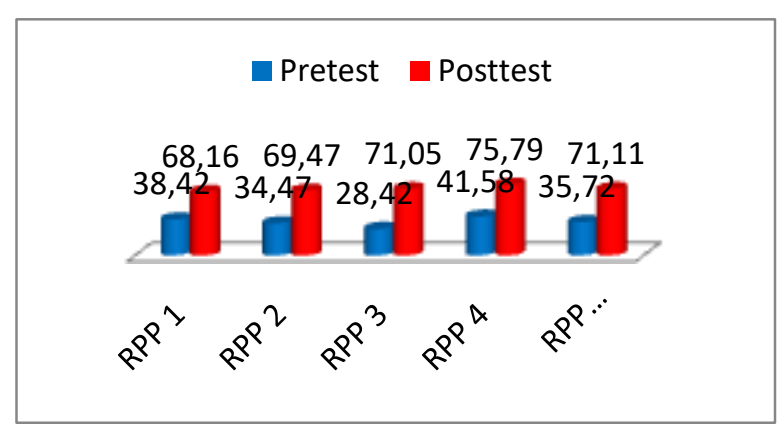

\section{Gambar 4. Hasil pre test dan post test sebelum dan sesudah menggunakan modul}

Keterangan :

OSebelum, Pesudah 


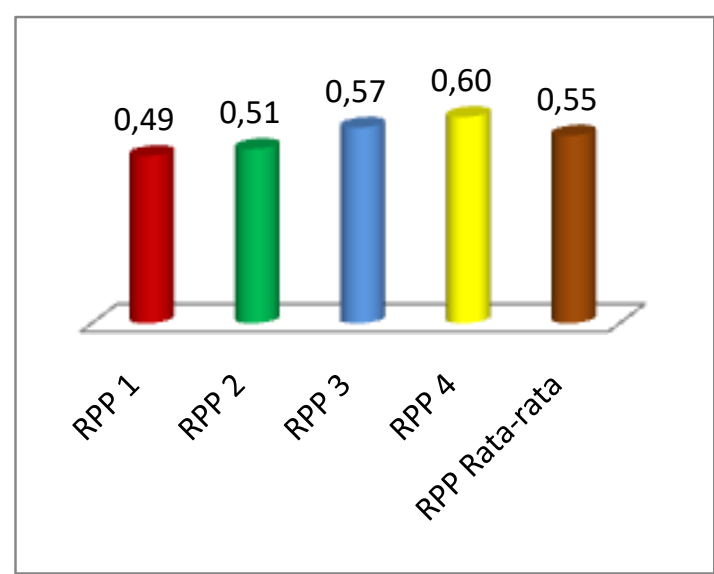

Gambar 5. n-Gain rata-rata per RPP

Berdasarkan gambar dapat diketahui bahwa hasil belajar pada RPP-1 nilai pretest 38,42 , nialai posttest 68,16 , terjadi peningkatan sebesar 29,74, diperoleh nilain-Gain sebesar 0,49, RPP-2 nilai pretest 34,47 dan nilai posttest 69,47. Terjadi peningkatan hasil belajar IPA dengan menggunakan pendekatan inkuiri terbimbing pada materi tanah dan keberlangsungan hidup sebesar 32, dan n-Gain sebesar 0,51. RPP-3 nilai pretest 28,42 dan nilai posttest 71,05, peningkatan sebesar 42,63 dengan nilai $\mathrm{n}$-Gain sebesar 0,57 dan pada RPP-4 nilai pretest 41,58 , nilai posttest 75,79 , peningkatan sebesar 34,21 dengan n-Gain 0,60.Rata - rata uji $n$-Gain dari RPP-1, RPP-2, RPP-3 dan RPP-4 adalah sebesar 0,55 yang menunjukkan adanya peningkatan hasil belajar dan penguasaan konsep peserta didik termasuk dalam kategori sedang dan tingkat. Hal ini disebabkan dengan pendekatan inkuiri terbimbing dapat menunjukan pemahaman peserta didik akan materi yang diajarkan guru sehingga lebih mudah untuk menguasai konsep materi tersebut. Hasil penelitian ini senada dengan penelitian Siregar, T dan Desry (2019) bahwa penelitian Inkuiri terbimbing dapat meningkatkan hasil belajar.

\section{SIMPULAN DAN SARAN SIMPULAN}

Berdasarkan hasil penelitian yang telah dilakukan dapat disimpulkan bahwa:

Tahapan pengembangan modul pembelajaran IPA terpadu berbasis inkuiri terbimbing pada materi tanah dan keberlangsungan kehidupan meliputi : analisis potensi dan masalah, pengumpulan data, desain produk, validasi desain, revisi desain, ujicoba produk, dan evaluasi.

Kelayakan modul sesuai data hasil validasi validator sebesar 88\%, respon guru IPA sebesar $90 \%$, dan respon peserta didik hasil uji coba skala kecil sebesar $89 \%$.

Peningkatan hasil belajar peserta didik kelas IX SMP Negeri 2 Manokwari sesuai data yang diperoleh yaitu rata-rata nilai pretest 35,72 menjadi 71,11 pada posttest dengan hasil uji n-Gain rata- rata sebesar 0,55 dengan kategori sedang.

\section{SARAN}

Modul IPA terpadu berbasis inkuiri terbimbing pada materi tanah dan keberlangsungan kehidupandapat dapat dikembangkan lebih lanjut sebagai salah satu upaya untuk meningkatkan keaktifan dan hasi belajar peserta didik.

\section{DAFTAR PUSTAKA}

Depdiknas .2006. Model Pengembangan SilabusMata Pelajaran dan Rencana pelaksanaan Pembelajaran IPA Terpadu SMP/MTs.Jakarta: Pusat Kurikulum, Balitbang Depdiknas.

Esti, R dan Virman 2018 Pengembangan Modul Pembelajaran Fisika Berbasis Discovery Learning Pada Materi Vektor Peserta Didik Kelas X SMA KPG Khas "Papua" Merauke. 
Kalemben,Simon . (2018). Pengembangan Modul IPA Terpadu Berbasis Inkuiri Terbimbing Untuk Meningkatkan Ketrampilan Proses Sains, Minat, dan Hasil Belajar Siswa Pada Materi Fotosintesis di kelas VIII SMP Negeri 9 Jayapura. Tesis Tidak diterbitkan. Jayapura : Program Studi Magister Pendidikan IPA Universitas Cenderawasih.

Nuh M. 2009. Implementasi Kurikulum 2013. Kemendikbud Republik Indonesia.

Prastowo.2012.Panduan Kreatif Membuat Bahan Ajar.Yogyakarta :Diva Press.

Putra S.R. (2012) Desain Belajar Mengajar Kreatif Berbasis Sains. Yogyakarta :Diva Press
Riduwan, 2012, Metode dan teknik penyusunan proposal penelitian, Bandung, Alfabeta

Siregar, T. (2011). Pendekatan Inquiri Based Learning (IBL). Jayapura: Logoz Publishing.

Siregar T dan Desri Natalia 2019, Modul Pengembangan Inkuiri Terbimbing Pada Materi Larutan Elektrolit Non Elektrolit, Jurnal Ilmu Pendidikan Indonesia.

Sugiyono. 2015. Metode Penelitian Pendidikan (pendekatan Kuantitatif, Kualitatif dan R \& D). Bandung: Alfabeta

Trianto.(2012). Model Pembelajaran IPA Terpadu. Jakarta: Bumi Aksara 